\title{
Study of Self-Compatibility Character Related to Seed Characteristics and Seedling Performance on Cocoa
}

\author{
Indah Anita-Sari ${ }^{1 *}$, Sobir $^{2}$, and Agung Wahyu Susilo ${ }^{1)}$ \\ ${ }^{1}$ Indonesian Coffee and Cocoa Research Institute, Jl. PB. Sudirman 90, Jember, Indonesia \\ ${ }^{2}$ Bogor Agriculture University, Kampus Darmaga, Bogor, Indonesia \\ ${ }^{*}$ Corresponding author: indah.sari83@yahoo.com. \\ Received: 22 June 2017 / Accepted: 14 July 2017
}

\begin{abstract}
Self-incompatibility is an important factor in limiting the yield of cacao (Theobroma cacao L.). The research aimed to study the effect of self-compatibility on cocoa related to pod and bean characteristics and seedling performance. The research was conducted at Kaliwining Research Station, Indonesian Coffee and Cocoa Research Institute, Jember and Bogor Agriculture University in Bogor. The research used completely randomized design with three clones as treatment and each treatment repeated three times. The three clones used had a different self-compatibility characteristics; NA 32 (self-incompatible), DR 2 and Sulawesi 2 (self-compatible). Fruit set, pod characteristics, bean characteristics and seedling performance were observed. The results showed that self compatible cocoa clones had higher of fruit set per cushion (4,7-7,9 fruit set per tree) than selfincompatible (1,9 fruit set per cushion). Sulawesi 2 as a self compatible cocoa clone showed the lowest of fallen fruit set per cushion after two and four weeks. Self compatible cocoa clones (Sulawesi 2 and DR 2) had greater pod and better bean quality than self incompatible (NA 32) included pod length, pod weight, pod girth, weight of wet beans per pod, number of beans per pod, volume per wet bean, weight of dry bean and weight of nib. While number of poorly beans per pod in self incompatible showed higher than self compatible clones. Seedling performance of self compatible showed better than self incompatible for plant height and stem diameter. Visually the seedling of self compatible showed homogeny than self incompatible and variant analysis of plant height showed that self compatible were lower than self incompatible.
\end{abstract}

Keyword: Bean, characteristics, cocoa, seedling, self-compatibility

\section{INTRODUCTION}

Occurrence of incompletely developed fruits, fruits with absent or poorly developed embryos and damage of fully developed fruits, adversely affect crop yield (Lindstrom et al., 2004). Some of common reasons for the formation of those type of fruits are the pollination failure, fertilization and physiological defects in ovary and embryo either genotypic and/or environmentally induced, such as water stress in anthesis and temperature after pollination or post fertilization (De GrandiHoffman \& Chambers, 2006). The research showed that sunflower production increased when honey bees (Apis melifera L.) participated actively in crop pollination. Pollinators would be necessary in commercial cultivar, where a high level of self-compatibility occurs. In these cultivars the level of self-compatibility had been improved, even though they showed considerable differences which were not always 
documented (DeGrandi Hoffman \& Chambers, 2006).

Cocoa is open pollinated and cross pollinated mostly by insect. Cocoa also has gametophytic self-compatibility system. Failure in self-pollination and fertilization are generally the results of anatomical, morphological and environmental barriers affecting pollen viability, stigma receptivity and pollen tube growth (Astiz et al., 2011). Pollinated may be essential for bean production during anthesis, but the importance of pollinators in andro-fertile has not been totally established. Development of cocoa plant based on selfcompatibility character can increase the bean productivity naturally because pollination and fertilization will occur by themselves. Decreasing of pollinator population is affected by the application of insecticide but not be a barrier for successfully of fertilization on cocoa. In different research showed that the failure of fertilization affected number of beans on cocoa. Cherelle wilt is not only caused by the physiological factor but largerly affected by failure of fertilization after pollination. Development of cocoa plant with self-compatibility give a good challenge to develop a number of beans successfully and completely fertilization process so it can develop a good pod and bean without need pollen from another genotype. Individual tree yield data collected at Gold Coast suggested that self-incompatibility was an important factor limiting the yield of cacao (Posnette, 1940). Plants that are naturally cross-pollinated and had self-compatibility characteristic require pollen from other varieties for normal fruit formation (Nanthachai, 1994; Syahruddin, 2012). Incomplete pollination can lead to the loculus and impact on fruit formation (not symmetric) and reduce the fruit qualities (Nanthachai, 1994). Merten (2003) reported that in dragon fruit which have self-compatible characteristic need to do artificial pollination using other pollen to produce a high percentage and bigger fruits. Self-pollinating results of interest from autogamous clones usually produce small fruits as opposed to cross pollination. Autogamy and self compatible flowers will produce larger fruits by cross-pollination than by self-pollination (Lichtenzveig et al., 2000). Adequate cross-pollination will produce fruit greater on size and weight than self-pollination and the fruit weight show a positive correlation to the number of beans (Merten, 2003). Specific clone composition for anticipating the incompatibility of certain clones is needed because self-incompatible plant generally also has cross-incompatible with other plants. The research aimed to study the effect of self-compatibility on cocoa related to pod and bean characteristics and seedling performance.

\section{MATERIALS AND METHODS}

The research was conducted at Kaliwining Experimental Station, Indonesian Coffee and Cocoa Research Institute (ICCRI) Jember, and Bogor Agriculture University in Bogor. The research used completely randomized design with three clones as treatments. Each treatment was repeated three times and each replication consisted of 10 samples as experimental units. The clones used had a distinct in self-compatibility characteristics refer to Susilo (2006) included NA 32 (self-incompatible), DR 2 and Sulawesi 2 (self-compatible). Pod and bean characteristics and seedling performance were observed. Pod and bean characteristics included fruit set per flower cushion, pod weight, pod girth, pod length, pod shape, bean weight, bean volume, number of beans, number of poorly bean, weight of dry bean, weight of nib. Fruit set observation was done by observing 30 cushions of flowers in each clone. Each cushion was counted for flower initiation which appeared up to fruit with two weeks old. Pod and bean qualities determination was done by observing 10 pod samples 
from open pollination in each clone. These samples were taken at Cocoa Germplasm Collection at ICCRI. Seedling performance was observed on number of survival seedlings, plant height, and stem diameter. Seedling was observed on two month old seedlings, each clone consisted of 40 seedlings. Stem diameter was observed $5 \mathrm{~cm}$ above the soil surface. Data analysis used ANOVA and analyzed by Duncan test used STAR program if there was a significant difference. Variation of seedling performance was analyzed using normality distribution by Minitab program.

\section{RESULTS AND DISCUSSION}

This experimental results showed that there was significant difference of fruit set per flower cushion between self-incompatible plant (NA 32) and self-compatible plant (Sulawesi 2 and DR 2). A self-incompatible plant showed fewer of fruit set per cushion than self-compatible plant. Decreasing of fruit set per cushion on self-incompatible occured since first week and most of the fruits were abort, meanwhile for self-compatible cocoa, although the decreasing of fruit set occured since first week, the fruit set still grew and formed pods (Figure 1).
Owais (2014) reported that selfing treatment on almond showed no fruit set $(0 \%)$. Timing of blooming overlapping in crosscompatible is a critical factor for high fruit set and consequently high yield (Oukabli et al., 2002). Fruit set could be related to the genetic self-compatibility and deduced by pollen tube growth as well as to the flower morphology, allowing the contact of stigma and anthers. Fruit set was also related to flower density and fruit size to define the real productivity level of each selection as selection showed highly significant different for their productivity by open pollination and by autogamy (Socias et al., 2004). The effect of self-fertilization in self-incompatible could reduce number of seeds up to $48 \%$ in Leavenworthia alabamica. Self-incompatible population exhibited significant in breeding depression in germination rate, flower number, pollen viability and lifetime male and female fitness (Busch, 2005). Trees were designated self-incompatible when less than $10 \%$ of the hand-pollination flowers set fruits. Cherelle wilt is not only caused by physiological factor but largely affected by failure of fertilization after pollination. Development of cocoa plant with selfcompatibility give a good challenge to developed

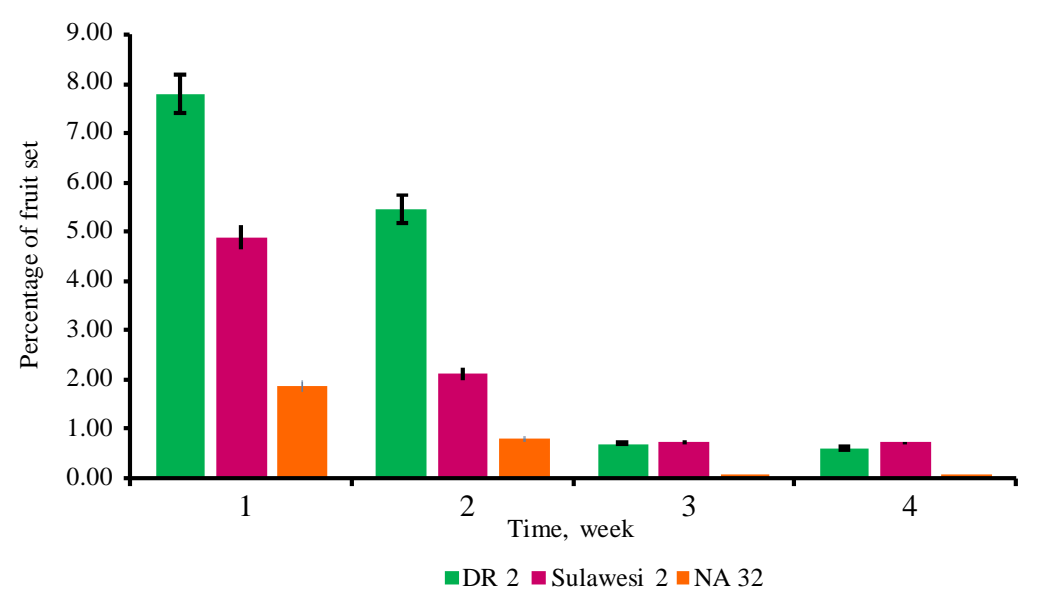

Figure 1. Percentage of fruit set on different self-compatibility characteristics on three clones during four weeks (vertical lines represent $\pm \mathrm{SD}$ ) 
a number of beans successfully and completely fertilization process so it can develop good pods and beans without need pollen from other genotypes (Posnette, 1940). Selfcompatibility become an interesting desirable trait in breeding. This result is important to make clone composition recommendation and this information showed that cocoa clones with self-incompatible are not able to be cultivated in monovarietal plantations (Oukabli et al., 2002).

The results showed that the self-compatibility characteristics could have an affect on pod and bean quality. NA 32 as an self-incompatible clone has small pod than DR 2 and Sulawesi 2 as self-compatible (Table 1). The size of beans also was bigger in Sulawesi 2 and DR 2 than NA 32. While, number of beans per pod was not significant different between self-compatible and self-incompatible.

Self-compatible plants are known to produce a high number of beans per pod under open pollination, while self-incompatible known produce a low number of seeds per pod under open pollination. Number of compatible pollen grains deposited on the stigma is probably low under open pollination, and the flowers require lower pollen quantities to set fruit, which resulted in a high frequency of low bean number per pod. Bean number produced by a plant reflects the genetic capacity and environment. Genetic capacity is the number of ovules available for fertilization, meanwhile for environmental factor the pollen available to fertilize those ovules, pollinator effectiveness, and resources available to develop bean from ovules that fertilized (Zorn-Arnold \& Howe, 2007). Limitation of pollen availability is common among plants that do not self-fertilize (Knight et al., 2005). Muntzing (1932) reported that the development of pod occured when there was a number of pollens, however the low of pollen number received by the pistil would produce fruits only to a certain size. Number of pollens influence the seed formation on cocoa. Selfcompatible plant in open pollination has a high possibility of plant to receive a number of pollens higher than in self-incompatible plant and it is used to form pods and beans. Merten (2003) reported that in adequate cross-pollination would produce fruit greater on size and weight than self-pollination and the fruit weight showed a positive correlation to the number of beans.

Abortion of the ovulatory occurred since there is no fertilization or there was death of zygote causing the variation of bean number that form ripe pods. The imperfection of bean number resulted in imperfect of pollination. Incomplete pollination can lead to the loculus and impact on fruit formation and reduce

Table 1 . Pod and bean quality on cocoa with different characters of self-compatibility

\begin{tabular}{|c|c|c|c|}
\hline \multirow[b]{2}{*}{ Characteristics } & \multicolumn{3}{|c|}{ Genotypes } \\
\hline & $\begin{array}{c}\text { DR } 2 \\
\text { Self-compatible }\end{array}$ & $\begin{array}{c}\text { Sulawesi } 2 \\
\text { Self-compatible } \\
\end{array}$ & $\begin{array}{c}\text { NA } 32 \\
\text { Self-Incompatible }\end{array}$ \\
\hline \multicolumn{4}{|l|}{ Pod quality } \\
\hline Pod length $(\mathrm{cm})$ & $23.37 \mathrm{a}$ & $19.93 \mathrm{~b}$ & $16.03 \mathrm{c}$ \\
\hline Pod girth $(\mathrm{cm})$ & $28.43 \mathrm{a}$ & $23.73 \mathrm{~b}$ & $16.01 \mathrm{c}$ \\
\hline Pod weight (g) & $628.9 \mathrm{a}$ & $494.67 \mathrm{~b}$ & $315.8 \mathrm{c}$ \\
\hline \multicolumn{4}{|l|}{ Bean quality } \\
\hline Weight of wet beans per pod $(\mathrm{g})$ & $140 \mathrm{a}$ & $123 \mathrm{a}$ & $75 \mathrm{~b}$ \\
\hline - Number of beans per pod & $38.23 \mathrm{a}$ & $34.17 \mathrm{ab}$ & $33.17 \mathrm{~b}$ \\
\hline - Number of poorly beans per pod & $1.00 \mathrm{~b}$ & $1.00 \mathrm{~b}$ & $3.67 \mathrm{a}$ \\
\hline Volume per wet bean $(\mathrm{mL})$ & $4.90 \mathrm{a}$ & $4.37 \mathrm{~b}$ & $3.90 \mathrm{c}$ \\
\hline Weight of dry bean $(\mathrm{g})$ & $1.18 \mathrm{a}$ & $0.93 \mathrm{~b}$ & $0.48 \mathrm{c}$ \\
\hline Weight of nib $(\mathrm{g})$ & $1.09 \mathrm{a}$ & $0.91 \mathrm{~b}$ & $0.44 \mathrm{c}$ \\
\hline
\end{tabular}


the fruit qualities (Nanthacai et al., 1994). Self-compatibility on cocoa plant occur not because of a failure of the timing of the pollen grain formation but the occurrence of failure after fertilization. In generally, self-compatibility will not be compatible with others and will form beans when receiving pollens from plants that are self-compatible although there are other research reported that selfincompatible plants could be compatible with others (Muntzing, 1932).

Self-incompatibility is an important mechanism that prevents inbreeding in flowering plants (de Nettancourt, 2001). Self-incompatible species develop zero to very low numbers of fruits after self-pollination due to the action of the gene products of the S-locus. Self-incompatibility also often show relatively low fruit set (Ferrer et al., 2009). Some predominant outcrossing, selfcompatible exhibit low seed set. The seed set is often polen limited in self-incompatible species (Larson \& Barret, 2000) jbecause female are more likely to receive either an inadequate quantity or quality of pollens (Ferrer et al., 2009).

Production of beans on most flowering plants is favored by pollinators visiting their flowers. The beans production take places in four phases: 1) pollination, time when pollen is transferred from anther to stigma, 2) germination of a pollen tube (from the pollen grain), which contains two male gametes, down the style into the ovary, 3) fertilization of eggs and nuclei in ovules, and 4) development of the embryos and then fertile beans (Knight et al., 2005). The bean production of most plant particularly those that are selfincompatible, is limited by access to pollen. This means that if the plants in a population had more pollen grains deposited on their stigmas they would have produced more seeds. Sounigo et al. cit. Sounigo et al. (2005) reported that there was possibility of a positive response, since the self-compatible trees were characterized by a higher ratio of productivity to bulk that the self-incompatible trees, though the difference was not significant. Lachenaud (2005) reported that the yield efficiency values were significantly higher in the high-yielding group and in the self-compatible group, compatibility was higher on average. Individual tree yield data collected at Gold Coast suggest that self-incompatibility is an important factor limiting the yield of cacao. It is least common in the Amelomiclo variety and very common in the Cundeamor, with Criollo intermediate (Posnette, 1940). Compatibility was significantly and positively correlated to yield but compatibility was not correlated to overall yield, and not to yield in the mature phase. However, for the initial effects, positive correlations were found between the compatibility rate and the two initial yields. The yield of the self-compatible group was significantly higher than that of the strictly selfincompatible group. Compatibility and "vigour" were not correlated (Lachenaud, 2005).

The results showed that there was differences morphological characteristics of pod between self-compatible and self-incompatible plant. DR 2 and Sulawesi 2 visually showed bigger than NA 32 (Figure 2). Selfcompatible showed a normal size and perfect shape of pod than the self-incompatible.



Figure 2. Performance of pod form self-incompatible plant (NA 32) and self-compatible plants (DR 2 and Sulawesi 2) 
Owais (2014) reported that one negative consequence of self pollination is irregular shape of the pod. Other studies said that there is not differences between self and cross pollination in morpho-physical traits. Different with this result that the morphophysical of pod of self-compatible looked better shape, normal pod and bigger than self-incompatible pod.

The analysis showed that there were differences of seedling growth between selfcompatible and self-incompatible progenies. Self-compatible progeny (Sulawesi 2 and DR 2) showed higher on height and diameter than self-incompatible (Na 32) (Figure 3). Sulawesi 2 showed the highest seedling, but the homogeneity of seedling both of selfcompatible and self-incompatible did not show significant different (Table 2).
Table 2. Characteristics of seedling half-sib from different cocoa clones with different self-compatiblity

\begin{tabular}{lrcc}
\hline & Average & Variance & St.Dev \\
\hline Plant height $(\mathrm{cm})$ & & & \\
DR 2 & 28.28 & 34.72 & 5.89 \\
Sulawesi 2 & 41.67 & 38.75 & 6.22 \\
NA 32 & 25.40 & 35.71 & 5.98 \\
Plant diameter (mm) & & & \\
DR 2 & 11.27 & 3.51 & 1.87 \\
Sulawesi 2 & 14.10 & 2.85 & 1.69 \\
NA 32 & 9.83 & 1.73 & 1.32 \\
\hline & & &
\end{tabular}

The mean of plant height of self compatible clones showed higher that self incompatible. Sulawesi 2 showed the highest than the others (Figure 3 ).

Visually, seedlings of self compatible clones (Sulawesi 2) showed homogeny than self incompatible (Na 32). Chauta-Mellizo et al. (2012) reported that deposition of self-pollen or pollen relatived could lead to inbred progeny that experienced inbreeding depression

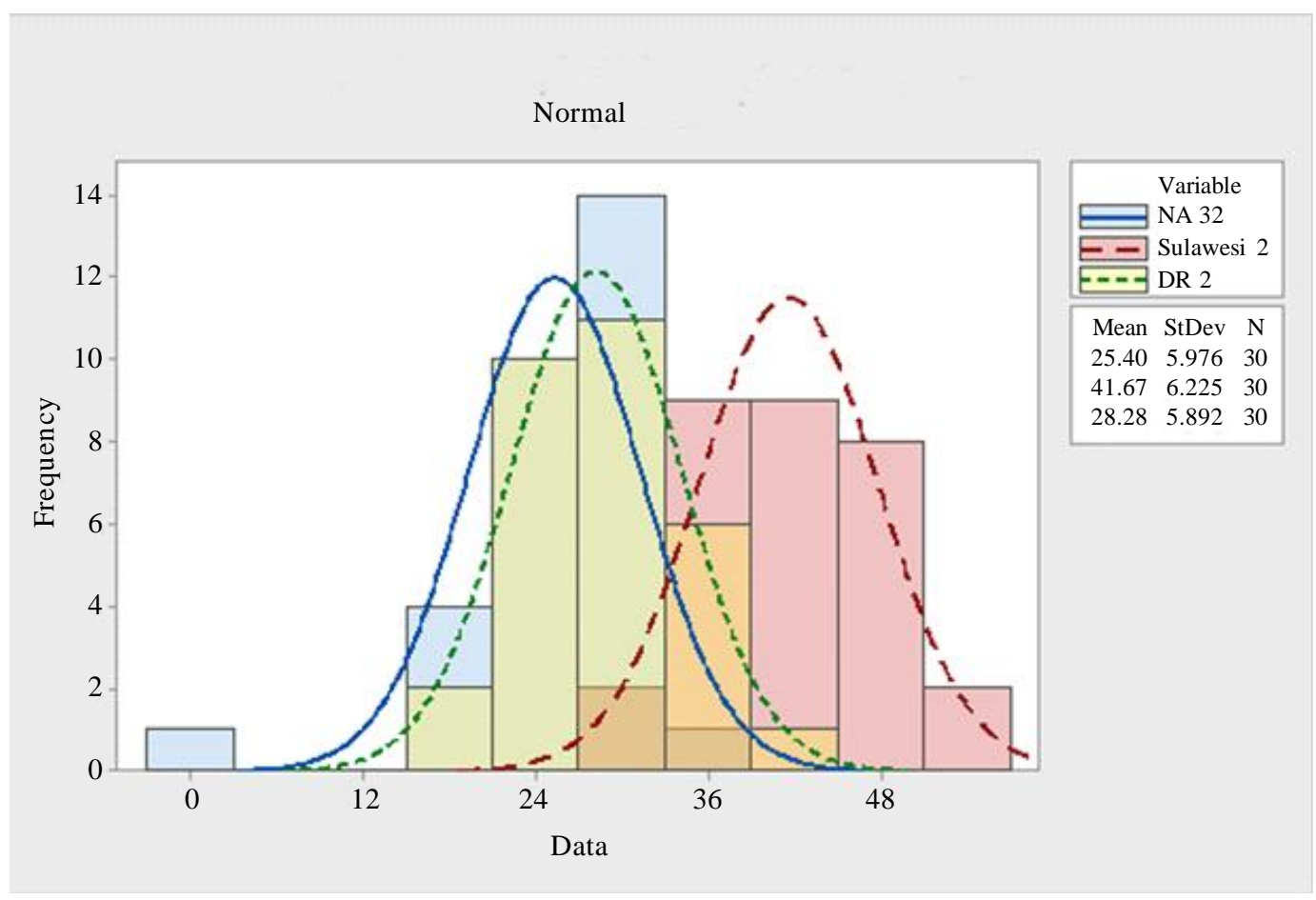

Figure 3. Distribution of plant height of two months old seedlings of Sulawesi 2, DR 2 and NA 33 
of fitness traits, including germination rate, growth and survival in comparison to outcrossed offspring.

\section{CONCLUSION}

Self-compatible cocoa clones showed higher fruit set per cushion than self incompatible cocoa clones. Morphologycally, selfcompatible cocoa clones had a good pod size and bean quality than self-incompatible except number of bean per pod. Performance of self-compatible cocoa seedling of was better than self-incompatible particularly for plant height, stem diameter and homogeneity of the seedling performance.

\section{ACKNOWLEDGEMENTS}

The authors would like to acknowledge the Director of Indonesian Coffee and Cocoa Research Institute for supporting this research. The authors also thank Sukarmin, Rudi Hartoyo, Pingkan Sugianto, Rizki Anjal Nugroho, and Akhmad Hidayatullah for their participation in this research.

\section{REFERENCES}

Astiz V.; L.A. Iriart; A. Flemmer \& L.F. Hernández (2011) Self-compatibility in modern hybrids of sunflower (Helianthus annuus L.): Fruit set in open and selfpollinated (bag isolated) plants grown in two different locations. Helia, 54, 129-138.

Busch, J.W. (2005). Inbreeding depression in self-incompatible and self-compatible populations of Leavenworthia alabamica. Heredity, 94, 159-165.

Chautá-Mellizoa, A.; S.A. Campbelb; M.A. Bonilllaa; J.S. Thalerb \& K. Povedac (2012). Effects of natural and artificial pollination on fruit and offspring. Basic and Applied Ecology, 13, 524-532.

De Grandi-Hoffman, G. \& M. Chambers (2006). Effects of honey bee (Hymenoptera: Apidae) foraging on seed set in selffertile sunflowers (Helianthus annuus L). Environmental Entomology, 35, 1103-1108.

de Nettancourt D. (2001). Incompatibility and Incongruity in Wild and Cultivated Plants, $2^{\text {nd }}$ eds. Springer-Verlag. Berlin.

Ferrer, A.M.; S.V. Good-Avila; C. Montana; C.A. Dominguez \& L.E. Eguiarte (2009). Effect of variation in self-incompatibility on pollen limitation and inbreeding depression in Flourensia cernua (Asteraceae) scrubs of contrasting density. Annuals of Botany, 103, 1077-1089.

Knight, T. M.; J.A. Steets; J.C. Vamosi; S.J. Mazer; M. burd; D.R. Dampbell; M.R. Dudash; M.O. Johnston; R.J. Mitchel, L. \& T. Ashman (2005). Pollen limitation of plant reproduction: pattern and process. Annual Review of Ecological Systems, 36, 467-497.

Lachenaud, P. \& G. Oliver (2005). Compatibility and duration of pod maturation in Guianan wild cocoa trees-preliminary results. Ingenic Newsletter, 10, 20-22.

Larson, B.M.H. \& S.C.H. Barret (2000). A comparative analysis of pollen limitation in flowering plants. Biological Journal of the Linnean Society, 69, 503-520.

Lichtenzverg, J.; S. Aboo; A. Nerd \& Y. Mirazhi (2000). Cytology and matingsystems in the climbing cacti Hylocereus and Selenicereus. American Journal of Botany, 87, 1058-1065.

Lindström, L.I.; M.E. García \& L.F. Hernández (2004). Morphology and distribution of incompletely developed fruits in sunflower (Helianthus annuus L.) capitula. p. 333-337. In: Proc. $16^{\text {th }}$ Int. Sunflower Conforence, Fargo, ND, USA. 
Merten, S. (2003). A review of Hylocereus production in the United States. Journal of PACD , 5, 98-105.

Muntzing, A. (1932). Cyto-genetic investigations on synthetic Galeopsis tetrahit. Hereditas XVI. 154p.

Nanthachai, S. (1964). Durian Fruit Development, Postharvest Physiology, Handling and Marketing in ASEAN. Kualalumpur, Malaysia.

Oukabli, A; A. Lansar; A. Walali; A. Abousalim; J. Egea \& N. Michaux-Ferrier (2002). Self and cross pollination effects on pollen tube growth andfertilization in self-compatible almond (Prunus dulcis). Journal Horticulture Science Biotechnology, 75, 739-744.

Oukabli A.; A. Lansari; Walali-Loudiyi \& S.J. Owais (2014). Self-incompatibility and effect of reciprocal cross and open pollination on fruit set and fruit characteristic in Jordanian almond landraces. American Journal of Agricultural and Biological Sciences, 9, 466-473.

Posnette, A.F. (1940). Self-incompatibility in cocoa. Tropical Agriculture, Trinidad and Tobacco, 17, 67-71.
Socias, R.; J.M. Alonso \& J.G. Aparisi (2004). Fruit set and productivity in almond as related to self-compatibility, flower morphology and bud density. The Journal of Horticultural Science and Biotechnology, 79, 754-758.

Sounigo, O.; R. Umaharan; Y. Christopher; A. Sankar \& S. Ramdahin (2005) Assessing the genetic diversity in the International Cocoa Genebank, Trinidad (ICG,T) using isozyme electrophoresis and RAPD. Genetic Research Crop Evolution, 52, 1111-1120.

Susilo, A.W. (2006). Kemampuan menyerbuk sendiri beberapa klon kakao (Theobroma cacao L.). Pelita Perkebunan, 22, 159-167.

Syahrudiin, K. (2012). Analisis Keragaman Beberapa Genotipe Durian (Durio Zibethinus Murr.) Menggunakan Penanda Morfologi dan Molekular (ISSR). Thesis. Institut Pertanian Bogor. Bogor.

Zorn-Arnold, B. \& H.F. Howe (2007). Density and seed set in a self-compatible forb, Penstemon digitalis (Plantaginaceae), with multiple pollinators. American Journal of Botany, 94, 1594-1602.

$* * 0 * *$ 